\title{
A serological, parasitological and clinical evaluation of untreated Chagas disease patients and those treated with benznidazole before and thirteen years after intervention
}

\author{
Girley Francisco Machado-de-Assis ${ }^{1 /+}$, Glaucia Alessio Diniz ${ }^{1}$, Roberto Araújo Montoya ${ }^{2}$, \\ João Carlos Pinto Dias ${ }^{3}$, José Rodrigues Coura ${ }^{4}$, George Luiz Lins Machado-Coelho ${ }^{1,5}$, \\ Pedro Albajar-Viñas ${ }^{6}$, Rosália Morais Torres ${ }^{7}$, Marta de Lana ${ }^{1,8}$
}

\begin{abstract}
${ }^{1}$ Núcleo de Pesquisas em Ciências Biológicas ${ }^{5}$ Departamento de Ciências Médicas ${ }^{8}$ Departamento de Análises Clínicas, Escola de Farmácia, Universidade Federal de Ouro Preto, Ouro Preto, Minas Gerais, Brasil Organização Pan-Americana da Saúde, Bogotá, Colômbia ${ }^{3}$ Centro de Pesquisas René Rachou-Fiocruz, Belo Horizonte, MG, Brasil ${ }^{4}$ Laboratório de Doenças Parasitárias, Instituto Oswaldo Cruz-Fiocruz, Rio de Janeiro, RJ, Brasil ${ }^{6}$ Departamento de Controle de Doenças Tropicais Negligenciadas, Organização Mundial da Saúde, Geneva, Switzerland ${ }^{7}$ Faculdade de Medicina, Universidade Federal de Minas Gerais, Belo Horizonte, MG, Brasil
\end{abstract}

The etiological treatment of Chagas disease is recommended for all patients with acute or recent chronic infection, but controversies remain regarding the benefit of chemotherapy and interpretations of the parasitological cure after etiological treatment. This study compares the laboratory and clinical evaluations of Chagas disease patients who were diagnosed 13 years earlier. Fifty-eight Chagas disease patients (29 treated with benznidazole and 29 untreated) were matched at the time of treatment based on several variables. Conventional serology revealed the absence of seroconversion in all patients. However, lower serological titres were verified in the treated group, primarily among patients who had the indeterminate form of the disease. Haemoculture performed 13 years after the intervention was positive for $6.9 \%$ and $27.6 \%$ of the treated and untreated patients, respectively. Polymerase chain reaction tests were positive for $44.8 \%$ and $13.8 \%$ of the treated and untreated patients, respectively. Patients who presented with the indeterminate form of the disease at the beginning of the study exhibited less clinical progression (17.4\%) compared with the untreated group (56.5\%). Therefore, this global analysis revealed that etiological treatment with benznidazole may benefit patients with respect to the clinical progression of Chagas disease and the prognosis, particularly when administered to patients with the indeterminate form of the disease.

Key words: Chagas disease - benznidazole - serological and clinical evaluation - Trypanosoma cruzi - etiological treatment

Chagas disease, also known as American trypanosomiasis, is an infection caused by the protozoan flagellate Trypanosoma cruzi, which was discovered 104 years ago by the Brazilian physician Carlos Chagas (1909). The main mechanism of transmission of this infection to humans is vectorial via triatomine bugs, but other routes of infection are possible, such as blood transfusion, organ transplantation, laboratory accidents and transplacental and oral routes (Dias 1999). Historically, Chagas disease has been considered endemic mainly in Latin America, where 10 million chronically infected individuals are distributed throughout 21 countries (WHO 2010). The epidemiology of Chagas disease has changed significantly in recent decades as a consequence of urbanisation and population movement, particularly migration (Schmunis 2007).

doi: 10.1590/0074-0276130122

Financial support: FAPEMIG (PPSUS-06/3242), CNPq (473885/2008-5)

GFM-de-A is funded by CAPES

+ Corresponding author: girleyfrancisco@nupeb.ufop.br

Received 28 February 2013

Accepted 4 July 2013
Chagas disease features an initial acute phase characterised by high levels of parasitaemia, but is generally asymptomatic or oligosymptomatic and rarely severe or lethal. The majority of chronically infected patients remain in the indeterminate clinical stage of the disease and approximately $30-40 \%$ of patients develop cardiac or gastrointestinal alterations (Prata 2001). The chronic phase of the disease is characterised by a low level of parasitaemia and the presence of anti-T. cruzi $\operatorname{IgG}$ antibodies.

To date, only two drugs have been demonstrated to be effective for Chagas disease chemotherapy: nifurtimox, a nitrofuran derivative manufactured by Bayer as Lampit $^{\circledR}$, and benznidazole, a nitroimidazole derivative previously manufactured by Roche as Rochagan ${ }^{\circledR}$ or Rodanil ${ }^{\circledR}$ and now manufactured by Laboratório Farmacêutico do Estado de Pernambuco in Brazil and as Abarax ${ }^{\circledR}$ by Laboratorio ELEA in Argentina. Both drugs may cause considerable side effects in some patients, particularly in older patients. In addition, these drugs are not recommended for pregnant women and patients with renal and hepatic dysfunctions. The best results in chemotherapy have been achieved for acute or recent chronic infections, with a lower rate of parasitological cure among more established chronic infections (Viotti et al. 1994, Andrade et al. 1996, Cançado 2002). Other studies have demonstrated that etiological treatment leads to a significant reduction in the development of electrocar- 
diographic alterations, a slower clinical progression and the prevention of severe chronic cardiopathy (Segura et al. 1994, Suasnabar et al. 2000, Sosa-Estani \& Segura 2006, Viotti et al. 2006, de Lana et al. 2009). The indication of etiological treatment during the chronic phase of Chagas disease is controversial, as demonstrated by the operational difficulties with the post-treatment follow-up of chronic Chagas disease patients and the diversity of criteria and methodologies used in evaluating therapeutic efficacy (Coura \& de Castro 2002, Coura \& Borges-Pereira 2011). From a serological, molecular and parasitological standpoint, the cure rates are highly variable when treatment is administered during the chronic phase of infection and the cure rates are dependent on the infection time and the time elapsed after the treatment evaluation (Coura \& de Castro 2002, Guedes et al. 2006, Marin-Neto et al. 2009). Higher cure rates have been observed in patients treated in the early chronic phase compared to the later chronic phase (Andrade et al. 1996, Sosa-Estani et al. 1998).

Currently, the Brazilian Consensus in Chagas Disease recommends etiological treatment for all patients during the acute and early chronic disease phases (MS 2005). A larger, clinical, multicentre, randomised study called BENEFIT is in progress to evaluate the benefits of treatment on the clinical progression of chronic Chagas heart disease (Marin-Neto et al. 2009). Another large study, TRAENA, is being conducted in Argentina to evaluate whether treatment with benznidazole can modify the natural evolution of chronic Chagas disease in adult patients. In addition, controversies remain regarding the benefits of Chagas disease chemotherapy and parasitological cure interpretations after etiological treatment because of the genetic differences in parasites, time of infection, treatment scheme, time of follow-up, methodologies used and cure criteria (Coura \& de Castro 2002).

The main goal of this study was to compare the laboratory [i.e., conventional serology, haemoculture and polymerase chain reaction (PCR)] and clinical [i.e., anamnesis, physical examination, electrocardiogram (ECG) and X-ray] progression of individuals from a known endemic area of Brazil who had been diagnosed with Chagas disease 13 years earlier.

\section{PATIENTS, MATERIALS AND METHODS}

Study design - This retrospective study used a casecontrol with a sample selection for the convenience of individuals who had received laboratory and clinical diagnoses of chronic Chagas disease 13 years prior. One patient group $(\mathrm{n}=29)$ was treated with benznidazole and the other group $(n=29)$ was untreated (control group). The treated and untreated patients were matched with respect to the clinical form of Chagas disease, gender, age and geographical locality. Before the intervention, 46 patients presented with the indeterminate clinical form of the disease, 10 were classified as having the discrete cardiac form and two had the digestive form (megaesophagus group I) according to the OMS/OPAS (1974) classification. All laboratory and clinical data obtained at the beginning of this study and 13 years later from both groups were compared and the current clinical form determined following the same criteria used at baseline (OMS/OPAS 1974).

Patients - A group of 58 patients (20 males and 38 females) born and living in the municipality of Berilo, Jequitinhonha Valley, state of Minas Gerais (MG), Brazil, a Chagas disease vector-controlled area, was studied. T. cruzi infection was diagnosed in all patients in 1997 using conventional serological tests, including indirect immunofluorescence and ELISA. At that time, all patients were also clinically evaluated by anamnesis, physical examination, ECG and thorax X-ray using the OMS/OPAS (1974) criteria, according to Montoya (1998). Of these patients, 29 (10 males and 19 females), aged six-37 years at the time of diagnosis, were etiologically treated with benznidazole ( $5 \mathrm{mg} / \mathrm{kg} / 60$ days). The majority ( $82.8 \%)$ of the patients were aged 22-37 years when treated. Thirteen years later, these patients were re-evaluated in parallel with 29 matched untreated patients (control group).

Before study inclusion, all patients or their legal guardians read and signed the consent term approved by the Ethical Committee for Human Research from René Rachou Research Centre, Oswaldo Cruz Foundation, Belo Horizonte, MG (process 007/2002).

Laboratory evaluation - Conventional serological tests - The serological evaluation was performed using sera samples obtained before and 13 years after the intervention. In-house ELISA, recombinant ELISA (recELISA) and indirect haemagglutination (IHA) were used to evaluate only the sera collected 13 years after the intervention. Positive and negative control sera were run in parallel. The serum samples from the treated patients (collected before and after the treatment) were stored at the Chagas Disease Laboratory, Federal University of Ouro Preto, MG and matched with the serum samples from the untreated patients (control group); the samples were collected and examined in parallel.

An "in-house" ELISA was performed based on a modification of the Voller et al. (1975) method, with $4.5 \mu \mathrm{g} / \mathrm{mL}$ of antigen obtained from T. cruzi Y strain, a serum dilution of 1:80 and peroxidase-anti-human $\operatorname{IgG}$ conjugate at a dilution of 1:7,500. The cut-off value calculated for each plate was the mean absorbance of 10 negative control serum samples plus two standard deviations (Santos et al. 2012).

The Chagatest-Wienner rec-ELISA kit was used (ELISA recombinant v.3.0; Wienner Laboratorios, Rosario, Argentina) and sera were processed according to the manufacturer's instructions. Positive and negative control sera were included in parallel and the cut-off was the mean absorbance of three negative control sera plus 0.3 optical densities (OD).

For the IHA assay, the Hemacruzi ${ }^{\circledR}$ (bioMérieux, Brazil) kit was used according to the manufacturer's instructions.

Parasitological and molecular methods - These methods were used only during the final patient evaluation performed in 2010. One blood sample was collected from each patient. A portion of the volume was used for the haemoculture and the other portion was used for the PCR. 
For haemoculture, the Chiari et al. (1989) methodology was used. Briefly, $30 \mathrm{~mL}$ of heparinised venous blood was centrifuged at 3,000 rpm for $10 \mathrm{~min}$ and the plasma was discarded. The pellet was resuspended in 15 $\mathrm{mL}$ of liver infusion tryptose (LIT) medium and centrifuged under the same conditions. After removing the supernatant, the pellet was resuspended in $15 \mathrm{~mL}$ of LIT, distributed into three tubes, maintained at $28^{\circ} \mathrm{C}$, homogenised every $48 \mathrm{~h}$ and examined at regular 30-day intervals for 120 days.

For the PCR, a modified methodology based on Gomes et al. (1998) was used. Blood samples $(5 \mathrm{~mL})$ were collected in an equal volume of $6 \mathrm{M}$ guanidine$\mathrm{HCl}$ and $0.2 \mathrm{M}$ EDTA, $\mathrm{pH}$ 8.0, as described by Ávila et al. (1991). The samples were kept at room temperature (RT) for seven days and then boiled in water for $10 \mathrm{~min}$ to cleave the DNA (Britto et al. 1993) before being stored at RT until processing. An aliquot of $200 \mu \mathrm{L}$ of the lysate was subjected to DNA extraction with the Wizard $^{\circledR} \mathrm{Ge}$ nomic DNA Purification kit (Promega, Cat A1125 Lot 262870). PCR amplifications were conducted in a $9 \mu \mathrm{L}$ mixture containing Tris- $\mathrm{HCl} 10 \mathrm{mM}(\mathrm{pH} 9.0), 0.1 \%$ Triton X-100 (Invitrogen São Paulo, SP, Brazil), 75 mM KCl (Invitrogen São Paulo), $3.5 \mathrm{mM} \mathrm{MgCl}{ }_{2}$ (Invitrogen São Paulo), $0.2 \mathrm{mM}$ of each deoxynucleotide (dATP, dCTP, dGTP, dTTP; Sigma, St. Louis, MO, EUA), 0.5 U of Platinum Taq DNA polymerase (Invitrogen São Paulo) and 10 pmol of each oligonucleotide primer [121(AAATAA TGTACGGGTGAGATGCATGA) and 122(GGTTCGA TTGGGGTTGGTGTAATATA)]. Two microlitres of the blood DNA sample was added to the reaction mixture. After an initial denaturation step of $5 \mathrm{~min}$ at $94^{\circ} \mathrm{C}, 35$ cycles of amplification were performed in a thermal cycler (Biocycler MJ96G), each cycle consisted of $1 \mathrm{~min}$ at $95^{\circ} \mathrm{C}$ for DNA denaturation, $1 \mathrm{~min}$ at $65^{\circ} \mathrm{C}$ for primer annealing and $1 \mathrm{~min}$ at $72^{\circ} \mathrm{C}$ for primer extension, followed by a final extension step of $10 \mathrm{~min}$ at $72^{\circ} \mathrm{C}$. Amplified DNA was visualised in silver-stained $6 \%$ polyacrylamide gels (Santos et al. 1993). All samples were processed in duplicate. Positive, negative and reagent controls were processed in parallel. Negative results were reevaluated with primers for the human beta-globin gene $\mathrm{PCO} 3$ (ACACAAACTGTGTTCACTAGC) and PCO4 (CAACTTCATCCACGTTCACC) as an amplification control for the reaction.

Clinical evaluation - The final clinical evaluation (in 2010) and final clinical classification of all patients were performed by three physicians, who followed the same criteria used before treatment, as recommended by OMS/OPAS (1974), including anamnesis, physical examination, ECG and thorax X-ray. Data from treated and untreated patients in 2010 were compared with the original data from each patient in 1997 obtained by Montoya (1998). The clinical progression of the disease was calculated by dividing the number of patients who evolved clinically (e.g., anamnesis, ECG and thorax Xray alterations) by the total number of patients.

Statistical analysis - Comparative analyses of the absorbance (OD) obtained by conventional ELISA during the two assessments (before and 13 years after etio- logical treatment) and for the comparative analysis of clinical forms were performed using the non-parametric Wilcoxon test (Figs 1, 2). Fisher's exact test was used to compare the proportion of positive haemoculture results, PCR and clinical progressions between the treated and untreated patients (Figs 3,4). The results were considered significant when $\mathrm{p}<0.05$.

\section{RESULTS}

In this study, the laboratory and clinical data from two matched Chagas patient groups (treated and untreated) were obtained before intervention (treatment) in 1997 and 13 years later (2010) and compared.

Laboratory evaluation - Serology - All patients displayed positive results in conventional serological tests. A more detailed analysis of the stored sera using an "in house" ELISA assay revealed that before treatment (1997), the median absorbance values displayed no significant differences between the treated and untreated groups ( $p>0.05$ ). After 13 years (in 2010), the serological evaluation revealed a lower absorbance reading in the sera of patients of the treated group compared with the untreated group $(\mathrm{p}<0.05)$ (Fig. 1A).

When the patients were grouped by the clinical form of the disease exhibited before treatment, a lower absorbance in the treated group with the indeterminate form of the disease was observed compared with the untreated group $(\mathrm{p}<0.05)$ (Fig. 1B). This absorbance difference was not observed (Fig. 1C) in the patients who had cardiac or digestive alterations before treatment.

The comparison of the absorbance of sera samples collected in the beginning of the study (1997) and 13 years after intervention (2010) revealed that in the treated group, the majority of patients presented stabilisation or lower serological reactivity $(\mathrm{p}>0.05)$ (Fig. 2A), whereas in the untreated group, the majority of the patients exhibited increased reactivity ( $\mathrm{p}<0.0001$ ) (Fig. 2B).

Parasitological and molecular evaluation Haemoculture revealed positive results in $6.9 \%$ and $27.6 \%$ of the treated and untreated patients, respectively, and these differences were significantly different (Fig. 3). PCR produced positive results in $44.8 \%$ and $13.8 \%$ of the treated and untreated patients, respectively, and these differences were also significant (Fig. 3).

Clinical evaluation - Table shows the age, gender and clinical form of each patient etiologically treated before and 13 years after the intervention.

Thirteen years after the intervention (treatment), clinical evaluation revealed that $27.6 \%$ of the treated patients and $65.5 \%$ of the untreated patients presented with disease progression $(p<0.05)$ (Fig. 4). When the patients were grouped according to the clinical form observed before treatment, the patients that received treatment during the indeterminate clinical form of the disease displayed less progression/evolution of the disease (17.4\%) compared with untreated patients (56.5\%) (Fig. 4). In the untreated group, all patients who exhibited cardiac or digestive alterations progressed clinically throughout this study. The data revealed a lower percentage of annual clinical progression in the treated group $(2.12 \%)$ com- 

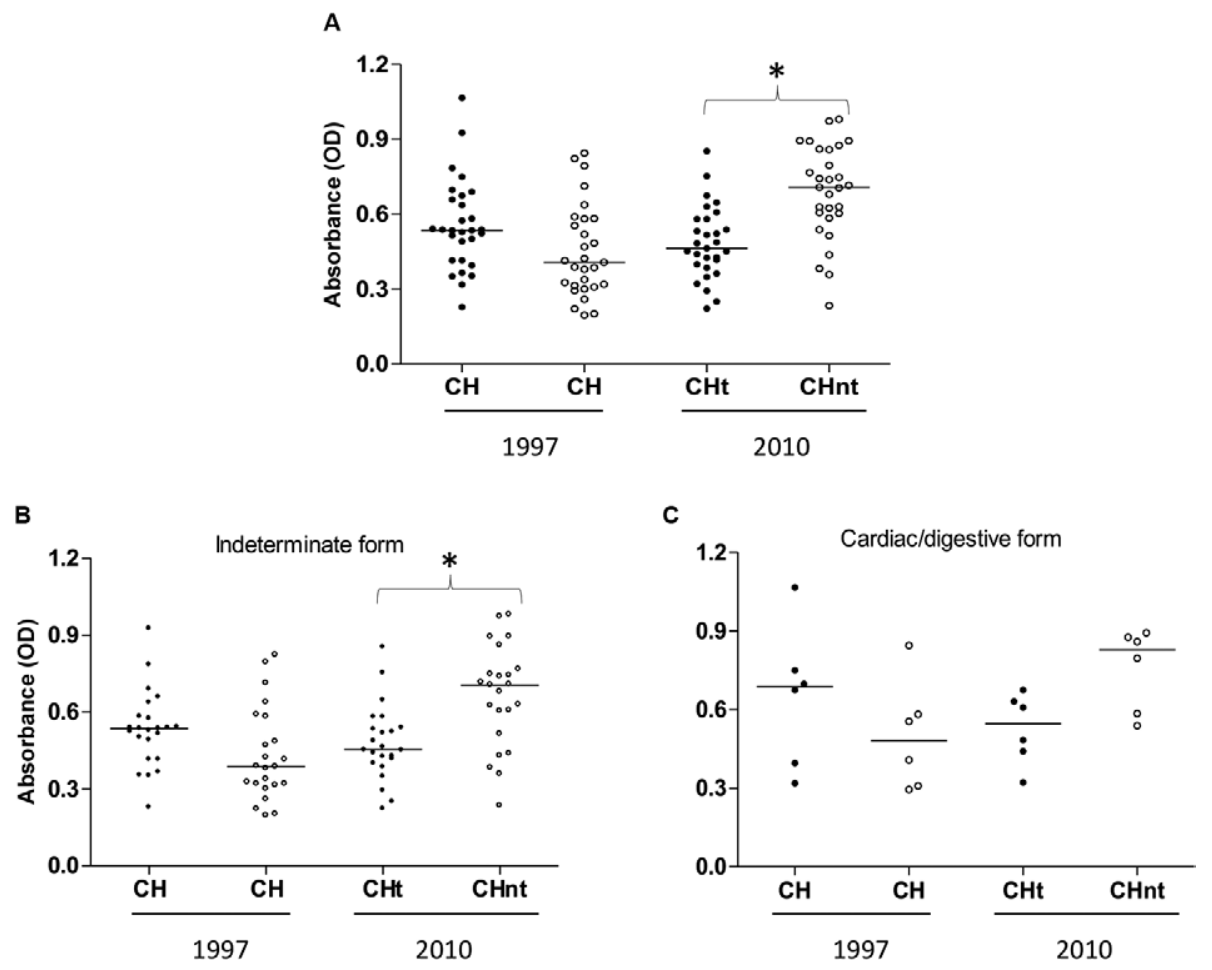

Fig. 1: anti-Trypanosoma cruzi IgG reactivity (ELISA) in serum samples from treated and untreated Chagas disease patients $(\mathrm{CH})$ at the beginning of treatment (1997) and 13 years later (2010) (A) and clinically categorised as having the indeterminate (B) or cardiac/digestive (C) form of the disease. CHt: Chagas disease treated patients; $\mathrm{CHnt}$ : Chagas disease not treated patients. Asterisks mean significant differences $(\mathrm{p}<0.05)$.

pared with the untreated group (5.03\%). This result was verified in the comparison of the annual index of clinical progression observed in the treated $(1.33 \%)$ and untreated (4.34\%) patients who presented with the indeterminate clinical form of the disease in the beginning of the study. However, this difference was not observed in the group of patients with cardiac and digestive alterations.

\section{DISCUSSION}

At the individual level, the treatment goals for T. cruzi infection are eliminating the parasite, decreasing the probability of clinical progression of the disease and indirectly affect $T$. cruzi transmission using vectorial and non-vectorial mechanisms of infection (Sosa-Estani 1993).

Several randomised studies have suggested that the etiological treatment of Chagas disease leads to negative results in serological tests and/or the prevention of electrocardiographic and clinical changes related to disease progression (Macêdo \& Silveira 1987, Miranda et al. 1994, Viotti et al. 1994, 2006, Fragata-Filho et al. 1995, Gallerano \& Sosa 2001, Fabbro et al. 2007, de Lana et al. 2009). However, other studies are contradictory and indicate that when treatment is administered during the chronic phase of the disease, the parasite is not eliminated, the progress of the disease is not interrupted; therefore, the complications of the infection are not prevented (Ianni et al. 1993, Amato Neto 1998, Ianni \& Mady 1998, Braga et al. 2000, Lauria-Pires et al. 2000). Controversies still exist regarding the real effects of the drugs used in human treatment on the clinical progression of Cha- gas disease, particularly during the chronic phase of the infection (Macêdo \& Silveira 1987, Braga et al. 2000, Lauria-Pires et al. 2000). These contradictions are most likely caused by the use of different treatment regimens and/or post-treatment evaluation protocols (Coura \& de Castro 2002). Consequently, despite the evidence that trypanocidal therapy may positively impact the clinical course of the disease in chronically infected patients (Sosa-Estani \& Segura 2006), there is neither a consensus nor sufficient data to support the routine use of the etiological treatment of Chagas disease at this stage of infection (Marin-Neto et al. 2009).

In this work, we comparatively evaluated the clinical and laboratory progression of etiologically treated and untreated Chagas disease patients after 13 years of follow-up.

All treated and untreated patients were reactive in the conventional serology (ELISA, IHA and rec-ELISA) 13 years after the intervention. A more detailed assessment using ELISA indicated a lower absorbance reading in the sera of treated patients compared with untreated patients. The lower absorbance rate was verified in the patients who were treated during the indeterminate form of the disease compared with the patients who displayed cardiac and/or digestive alterations before the treatment. After the treatment, decreased serological titres have been observed in several studies (Andrade et al. 1996, Sosa-Estani et al. 1998, Fabbro et al. 2007, Fernandes et al. 2009, Viotti et al. 2011), but the decay occurs slowly, particularly among patients treated during the chronic 
A

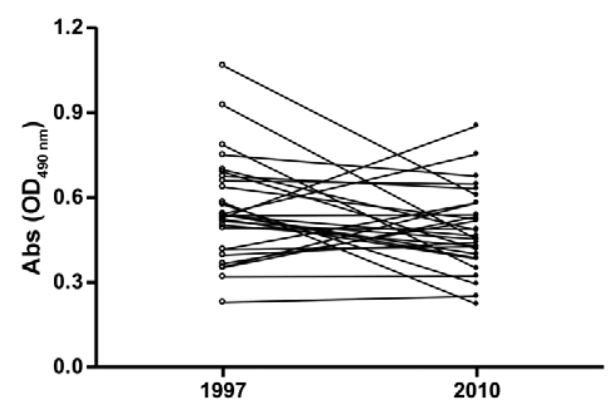

B

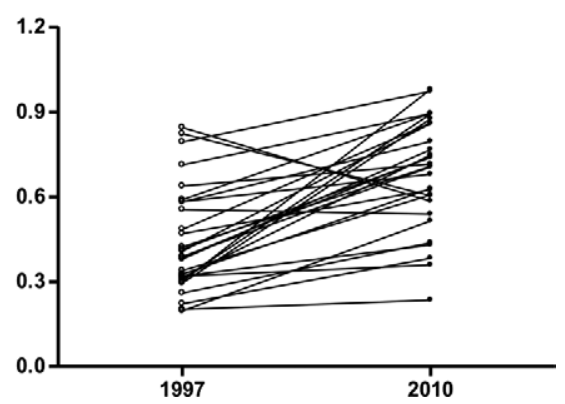

Fig. 2: optical density (OD) of serum samples from patients infected with Trypanosoma cruzi in the treated and untreated groups at the beginning of the study (1997) and 13 years after intervention (2010).

phase of the disease; this result justifies the need for several years of follow-up to verify the parasitological cure. Sosa-Estani et al. (1998) evaluated children treated with benznidazole during the indeterminate form of the disease during four years of follow-up and observed a significant decrease in serological titres in the treated patients, whereas no changes were observed among the patients who received placebos. This result may be because the patients were young ( $<12$ years), in which case the decrease of specific antibodies is more precocious.

Haemoculture is an important parameter for posttreatment evaluation because when positive the therapeutic failure is evident (Coura \& de Castro 2002). This technique revealed therapeutic failure in two/29 (6.9\%) of the patients in the treated group and was positive in eight/29 $(27.6 \%)$ of the patients in the untreated group. Haemoculture is useful for monitoring parasitological cures, but negative results must be carefully analysed because they do not necessarily indicate a cure because of low parasitaemia, which is characteristic of chronic patients (particularly treated patients) because of the intermittent nature of the parasitaemia, which can explain the low sensitivity of this parasitological method (Chiari et al. 1989, Junqueira et al. 1996, Coura et al. 1997, Gomes et al. 1999). Our data corroborated the work of Castro et al. (2006) who evaluated treated and untreated patients and observed a high prevalence of positive haemoculture results in an untreated patient group compared with a treated group.

PCR revealed positivity in $44.8 \%$ of the treated patients and $13.8 \%$ of the untreated group. More studies are necessary to verify the results obtained by this methodology in the context of the follow-up of treated patients compared with other laboratorial methods employed in humans and experimental models for the evaluation of treatment efficacy. Although the PCR technique is of higher sensitivity than haemoculture, these PCR results can be also attributed to the intermittent nature of the parasitaemia in chronic patients. Moreover, the blood samples examined in both methods (haemoculture and PCR) were not the same (Galvão et al. 2003, Britto 2009), but collected at the same time in different tubes. It is important to highlights that the global serological results of the treated patients did not show parasitological cure, according to the classic cure criteria (WHO 2002). This

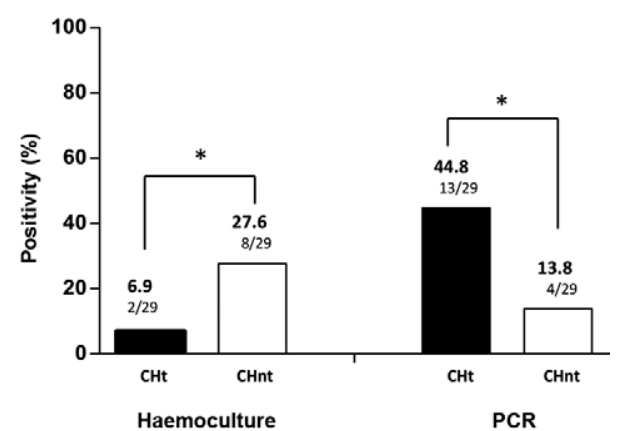

Fig. 3: percentage of positivity of the parasitological method (haemoculture) and molecular test [polymerase chain reaction (PCR)] between patients infected by Trypanosoma cruzi treated $(\mathrm{CHt})$ and untreated (CHnt) after 13 years of follow-up. Asterisks mean significant differences $(\mathrm{p}<0.05)$.

is not surprising because previous evaluation by PCR of these same patients (de Lana et al. 2009) four years before revealed also high percentage of positivity $(85.2 \%)$. However, it is important to highlight that this percentage was obtained two blood samples: the first with $64 \%$ and the second $54 \%$ of positivity. In the present work, were only one blood sample was examined. Moreover, the reaction controls show the reliability of the technique [in both phases, DNA extraction (amplification of human beta-globin gene) and PCR reaction] and eliminate the possibility of risk of contamination by k-DNA aerosol. Thus, some of the patients still have the infection or at least kDNA of T. cruzi in their bloodstreams. The results obtained may be also explained due the intermittent character of the parasitaemia and because only one sample of each patient was evaluated.

After 13 years of follow-up, the clinical evaluation revealed that $27.6 \%$ of the treated patients showed clinical progression and $65.5 \%$ of patients in the untreated group did as well. These results indicate that etiological treatment significantly delays the clinical progression of the disease, even in cases in which a parasitological cure was not yet observed. These data confirm the reports of several other authors that comparatively 
TABLE

Distribution of the patients etiological treated according to age when treated, gender and clinical form before and 13 years after treatment

\begin{tabular}{|c|c|c|c|c|}
\hline \multirow[b]{2}{*}{ Patients } & \multirow[b]{2}{*}{ Age } & \multirow[b]{2}{*}{ Sex } & \multicolumn{2}{|c|}{ Clinical form } \\
\hline & & & $\begin{array}{l}\text { Before } \\
(1997)\end{array}$ & $\begin{array}{l}\text { After } \\
(2010)\end{array}$ \\
\hline $1^{a}$ & 37 & $\mathrm{~F}$ & IF & CF mild \\
\hline $2^{a}$ & 33 & M & IF & CF mild \\
\hline $3^{a}$ & 6 & $\mathrm{~F}$ & IF & CF mild \\
\hline $4^{a}$ & 34 & $\mathrm{~F}$ & IF & CF mild \\
\hline 5 & 10 & M & IF & IF \\
\hline 6 & 23 & $\mathrm{~F}$ & IF & IF \\
\hline 7 & 25 & M & IF & IF \\
\hline 8 & 27 & M & IF & IF \\
\hline 9 & 30 & $\mathrm{~F}$ & IF & IF \\
\hline 10 & 25 & $\mathrm{~F}$ & IF & IF \\
\hline 11 & 28 & M & IF & IF \\
\hline 12 & 28 & M & IF & IF \\
\hline 13 & 31 & M & IF & IF \\
\hline 14 & 34 & $\mathrm{~F}$ & IF & IF \\
\hline 15 & 30 & $\mathrm{~F}$ & IF & IF \\
\hline 16 & 29 & $\mathrm{~F}$ & IF & IF \\
\hline 17 & 29 & $\mathrm{~F}$ & IF & IF \\
\hline 18 & 16 & $\mathrm{~F}$ & IF & IF \\
\hline 19 & 25 & $\mathrm{~F}$ & IF & IF \\
\hline 20 & 33 & $\mathrm{~F}$ & IF & IF \\
\hline 21 & 31 & $\mathrm{M}$ & IF & IF \\
\hline 22 & 37 & $\mathrm{~F}$ & IF & IF \\
\hline 23 & 14 & $\mathrm{~F}$ & IF & IF \\
\hline 24 & 23 & $\mathrm{~F}$ & CF mild & CF mild \\
\hline 25 & 30 & $\mathrm{~F}$ & CF mild & CF mild \\
\hline $26^{a}$ & 16 & M & CF mild & CF moderate \\
\hline $27^{a}$ & 34 & $\mathrm{M}$ & CF mild & CF moderate \\
\hline $28^{a}$ & 22 & $\mathrm{~F}$ & CF mild & CF severe \\
\hline $29^{a}$ & 26 & $\mathrm{~F}$ & $\mathrm{DF}\left(1^{\circ}\right)$ & $\mathrm{DF}\left(3^{\circ}\right)$ \\
\hline
\end{tabular}

a: patients that showed clinical progression after 13 years; $\mathrm{CF}$ : cardiac form; DF: digestive form; F: female; IF: indeterminate form; M: male.

evaluated groups of treated and untreated patients (Viotti et al. 1994, Fabbro et al. 2000, 2007, Gallerano \& Sosa 2001). Viotti et al. (2006) evaluated groups of patients with $T$. cruzi infection who were untreated or treated with benznidazole and revealed that the treated patients showed less disease progression ( $4 \%$ vs. $14 \%$ ) or developed fewer ECG abnormalities ( $5 \%$ vs. 16\%) compared with untreated patients. These authors also demonstrated that treatment intervention was associated with reduced clinical progression of Chagas disease and a bet-

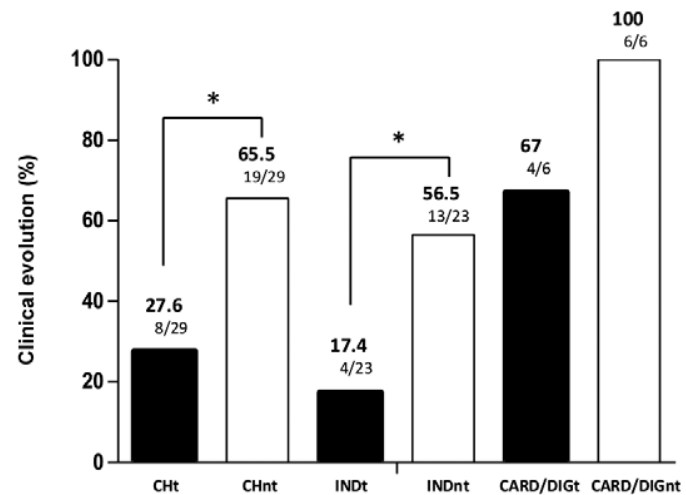

Fig. 4: clinical progression among Chagas disease patients treated (CHt) and untreated (CHnt) infected with Trypanosoma cruzi after 13 years of follow-up and grouped by the indeterminate (IND) treated (INDt), IND untreated (INDnt), and cardiac (CARD)/digestive (DIG) forms of the disease (DIGnt: DIG untreated; DIGt: DIG treated) based on clinical scores at the beginning of the study. Asterisks mean significant differences $(\mathrm{p}<0.05)$.

ter prognosis. Fabbro et al. (2007) evaluated 111 patients with Chagas disease (54 treated and 57 untreated) and observed a $37 \%$ seroconversion in the treated group and a $27.8 \%$ decrease in serological titres. Moreover, the patients in the untreated group exhibited stable serological titres. The percentage of clinical progression was 3.7\% in the treated group and $15.8 \%$ in the untreated group, which suggests that treatment induces a protective effect against the clinical progression of Chagas disease. This observation was more evident in the patients who had the indeterminate form of the disease at the beginning of the study. In this group, the clinical progression was observed in $17.4 \%$ of the treated patients and $56.5 \%$ of the untreated patients. These results indicate that treatment may prevent disease progression and reveals a better prognosis for patients treated during the indeterminate form of the disease, which confirms the findings of other studies (Gallerano \& Sosa 2000, Viotti et al. 2006, de Lana et al. 2009). However, the number of treated patients who displayed cardiac and digestive alterations prior to treatment was low to allow a definitive interpretation regarding the prognosis of the disease following etiological treatment.

This retrospective, comparative study matched treated and untreated Chagas patients by the clinical form of the disease before intervention (treatment) and by gender, age and geographical locality using laboratory and clinical evaluations. Even considering the low number of patients overall, this study revealed that the etiological treatment with benznidazole may benefit patients during the clinical progression of the disease and provide a better prognosis, particularly when the treatment is administered to patients with the indeterminate form of the disease.

\section{ACKNOWLEDGEMENTS}

To the municipality of Berilo, for the facilities provided for this work. 


\section{REFERENCES}

Amato Neto V 1998. Terapêutica da forma crônica da doença de Chagas. Tratamento específico da infecção pelo Trypanosoma cruzi. Arq Bras Cardiol 70: 63-64.

Andrade ALSS, Zicker F, Oliveira RM, Silva SA, Luquetti AO, Travassos LR, Almeida IC, Andrade SS, Andrade JG, Martelli CMT 1996. Randomized trial of efficacy of benznidazole in treatment of early Trypanosoma cruzi infection. Lancet 348: 1407-1413.

Ávila HA, Sigman DS, Cohen LM, Millikan S, Simpson L 1991. Polymerase chain reaction amplification of Trypanosoma cruzi kinetoplast minicircle DNA isolated from whole blood lysates: diagnosis of chronic Chagas disease. Mol Biochem Parasitol 48: 211-221.

Braga MS, Lauria-Pires L, Argañaraz ER, Nascimento RJ, Teixeira ARL 2000. Persistent infection in chronic Chagas disease patient treated with anti-Trypanosoma cruzi nitroderivates. Rev Inst Med Trop Sao Paulo 42: 157-161.

Britto C, Cardoso MAB, Wincker P, Morel CM 1993. A simple protocol for the physical cleavage of Trypanosoma cruzi kinetoplast DNA present in blood samples and its use in polymerase chain reaction (PCR)-based diagnosis of chronic Chagas disease. Mem Inst Oswaldo Cruz 88: 171-172.

Britto CC 2009. Usefulness of PCR-based assays to assess drug efficacy in Chagas disease chemotherapy: value and limitations. Mem Inst Oswaldo Cruz 104 (Suppl. I): 122-135.

Cançado JR 2002. Long term evaluation of etiological treatment of Chagas disease with benznidazole. Rev Inst Med Trop Sao Paulo 44: 29-37.

Castro AM, Luquetti AO, Rassi A, Chiari E, Galvão LMC 2006. Detection of parasitemia profiles by blood culture after treatment of human chronic Trypanosoma cruzi infection. Parasitol Res 99: 379-383.

Chagas C 1909. Nova tripanozomiaze humana. Estudos sobre a morfolojia e o ciclo evolutivo do Schizotrypanum cruzi n. gen., n. sp., ajente etiolojico de nova entidade morbida do homem. Mem Inst Oswaldo Cruz 1: 159-218.

Chiari E, Dias JCP, Lana M, Chiari CA 1989. Hemocultures for the parasitological diagnosis of human chronic Chagas disease. Rev Soc Bras Med Trop 22: 19-23.

Coura JR, Abreu LL, Wilcox HPF, Petana W 1997. Estudo comparativo controlado com emprego de benzonidazole, nifurtimox e placebo na forma crônica da doença de Chagas em uma área de campo com transmissão interrompida. I - Avaliação preliminar. Rev Soc Bras Med Trop 30: 139-144.

Coura JR, Borges-Pereira J 2011. Chronic phase of Chagas disease: why should it be treated? A comprehensive review. Mem Inst Oswaldo Cruz 106: 641-645.

Coura JR, de Castro SL 2002. A critical review on Chagas disease chemotherapy. Mem Inst Oswaldo Cruz 97: 3-24.

de Lana M, Lopes LA, Martins HR, Bahia MT, Machado-de-Assis GF, Wendling AP, Martins-Filho OA, Montoya RA, Dias JCP, Albajar-Viñas P, Coura JR 2009. Clinical and laboratory status of patients with chronic Chagas disease living in a vector-controlled area in Minas Gerais, Brazil, before and nine years after aetiological treatment. Mem Inst Oswaldo Cruz 104: 1139-1147.

Dias JCP 1999. Epidemiologia. In Z Brener, ZA Andrade, M BarralNetto (org.), Trypanosoma cruzi e doença de Chagas, Guanabara Koogan, Rio de Janeiro, p. 48-74.

Fabbro DL, Streiger ML, Arias ED, Bizai ML, Del Barco M, Amicone NA 2007. Trypanocide treatment among adults with chronic
Chagas disease living in Santa Fe city (Argentina), over a mean follow-up of 21 years: parasitological, serological and clinical evolution. Rev Soc Bras Med Trop 40: 1-10.

Fabbro DS, Arias E, Streiger M, Piacenza M, Ingaramo M, Del Barco M, Amicone N 2000. Evolutive behavior towards cardiomyopathy of treated (nifurtimox or benznidazole) and untreated chronic chagasic patients. Rev Inst Med Trop Sao Paulo 42: 99-109.

Fernandes CD, Tiecher FM, Balbinot MM, Liarte DB, Scholl D, Steindel M, Romanha A 2009. Efficacy of benznidazol treatment for asymptomatic chagasic patients from state of Rio Grande do Sul evaluated during a three years follow-up. Mem Inst Oswaldo Cruz 104: 27-32.

Fragata-Filho AA, da Silva MA, Boainain E 1995. Etiologic treatment of acute and chronic Chagas disease. Sao Paulo Med J 113: 867-872.

Gallerano RH, Sosa RR 2001. Resultados de un estudio a largo plazo con drogas antiparasitarias en infectados chagásicos crônicos. Rev Fed Arg Cardiol 30: 289-296.

Gallerano RH, Sosa RR 2000. Interventional study in the natural evolution of Chagas disease. Evaluation of specific antiparasitic treatment. Retrospective-prospective study of antiparasitic therapy. Rev Fac Cien Med Univ Nac Cordoba 57: 135-162.

Galvão LMC, Chiari E, Macedo AM, Luquetti AO, Silva SA, Andrade ALSS 2003. PCR assay for monitoring Trypanosoma cruzi parasitemia in childhood after specific chemotherapy. J Clin Microbiol 41: 5066-5070.

Gomes ML, Galvão LM, Macedo AM, Pena SD, Chiari E 1999. Chagas disease diagnosis: comparative analysis of parasitologic, molecular and serologic methods. Am J Trop Med Hyg 60: 205-210.

Gomes ML, Macedo AM, Vago AR, Pena SDJ, Galvão LMC, Chiari E 1998. Trypanosoma cruzi: optimization of polymerase chain reaction for detection in human blood. Exp Parasitol 88: 28-33.

Guedes PMM, Fietto JLR, Lana M, Bahia MT 2006. Advances in Chagas disease chemotherapy. Antiinfect Agents Med Chem 5: 175-186.

Ianni BM, Arteaga E, Mady CL 1993. Uso do benzonidazol em chagásicos na forma indeterminada: resultados a longo prazo. Arq Bras Cardiol 61 (Suppl. 2): 130.

Ianni BM, Mady C 1998. Terapêutica da forma crônica da doença de Chagas. É eficaz o tratamento etiológico? Arq Bras Cardiol 70: $59-61$.

Junqueira ACV, Chiari E, Wincker P 1996. Comparison of the polymerase chain reaction with two classical parasitological methods for the diagnosis of Chagas disease in an endemic region of northeastern Brazil. Trans R Soc Trop Med Hyg 90: 129-132.

Lauria-Pires L, Braga M, Vexenat AC, Nitz N, Simões-Barbosa A, Tinoco DL, Teixeira ARL 2000. Progressive chronic Chagas heart disease ten years after treatment with anti-Trypanosoma cruzi nitroderivatives. Am J Trop Med Hyg 63: 111-118.

Macêdo VO, Silveira CA 1987. Perspectiva da terapêutica específica na doença de Chagas. Experiência na forma indeterminada. Rev Soc Bras Med Trop 20 (Suppl. 2): 24-26.

Marin-Neto JA, Rassi Jr A, Avezum Jr A, Mattos AC, Rassi A 2009. The BENEFIT trial: testing the hypothesis that trypanocidal therapy is beneficial for patients with chronic Chagas heart disease. Mem Inst Oswaldo Cruz 104 (Suppl. I): 319-324.

Miranda L, Campos G, Marins N, Lobo V 1994. História natural da forma crônica da doença de Chagas $\mathrm{x}$ tratamento específico. Rev Centro-Oeste Cardiol 1: 25-29. 
Montoya RA 1998. Morbidade da doença de Chagas no município de Berilo, Minas Gerais, Brasil. Estudos seccional e longitudinal da cardiopatia chagásica crônica (1987 - 1997), PhD Thesis, Instituto Oswaldo Cruz, Rio de Janeiro, 153 pp.

MS - Ministério da Saúde 2005. Consenso brasileiro em doença de Chagas. Rev Soc Bras Med Trop 38 (Suppl. 3): 1-29.

OMS/OPAS - Organización Mundial de la Salud/Organización Panamericana de la Salud 1974. Aspectos clínicos de la enfermedad de Chagas. Informe de una reunión conjunta OMS/OPAS de investigadores. Bol Oficina Sanit Panam 76: 141-158.

Prata A 2001. Clinical and epidemiological aspects of Chagas disease. Lancet Infect Dis 1: 92-100.

Santos FR, Pena SD, Epplen JT 1993. Genetic and population study of a Y-linked tetranucleotide repeat DNA polymorphism with a simple non-isotopic technique. Hum Genet 90: 655-656.

Santos LS, Torres RM, Machado-de-Assis GF, Bahia MT, Martins HR, Teixeira-Carvalho A, Coelho-dos-Reis JGA, Albajar-Viñas P, Martins-Filho OA, Lana M 2012. In house ELISA method to analyze anti-Trypanosoma cruzi IgG reactivity for differential and evaluation of Chagas disease morbidity. Rev Soc Bras Med Trop 45: 35-44.

Schmunis GA 2007. Epidemiology of Chagas disease in non endemic countries: the role of international migration. Mem Inst Oswaldo Cruz 102 (Suppl. I): 75-85.

Segura MA, de Raspi EM, Basombrio MA 1994. Reversibility of muscle and heart lesions in chronic Trypanosoma cruzi infected mice after late trypanomicidal treatment. Mem Inst Oswaldo Cruz 89: 213-216.

Sosa-Estani S 1993. Tratamiento específico anti-T. cruzi. In R Madoeri, C Madoeri, MI Cámera (eds.), Actualización en enfermedad de Chagas, Organización Congreso Facultad de Medicina, Buenos Aires, p. 279-287.
Sosa-Estani S, Segura EL 2006. Etiological treatment in patients infected by Trypanosoma cruzi: experiences in Argentina. Current Opin Infect Dis 19: 583-587.

Sosa-Estani S, Segura EL, Ruiz AMR, Velazquez E, Porcel BM, Yampotis C 1998. Efficacy of chemotherapy with benznidazole in children in the indeterminate phase of Chagas disease. $\mathrm{Am} \mathrm{J}$ Trop Med Hyg 59: 526-529.

Suasnabar DF, Arias E, Streiger M, Piacenza M, Ingaramo M, Del Barco M, Amicone N 2000. Evolutive behavior towards cardiomyopathy of treated (nifurtimox or benznidazole) and untreated chronic chagasic patients. Rev Inst Med Trop Sao Paulo 42: 99-109.

Viotti R, Vigliano C, Álvarez MG, Lococo B, Petti M, Bertocchi G, Armenti A, de Rissio AM, Cooley G, Tarleton R, Laucella S 2011. Impact of aetiological treatment on conventional and multiplex serology in chronic Chagas disease. PLoS Negl Trop Dis 5: e1314.

Viotti R, Vigliano C, Armenti H, Segura E 1994. Treatment of chronic Chagas disease with benznidazole: clinical and serologic evolution of patients with long-term follow-up. Am Heart J 127: 151-162.

Viotti R, Vigliano C, Lococo B, Bertocchi G, Petti M, Alvarez MG, Postan M, Armenti A 2006. Long-term cardiac outcomes of treating chronic Chagas disease with benznidazole versus no treatment: a nonrandomized trial. Ann Intern Med 144: 724-734.

Voller A, Draper C, Bidwell DE 1975. Microplate enzyme-linked immunosorbent assay (ELISA) for Chagas disease. Lancet 305: 426-428.

WHO - World Health Organization 2002. Control of Chagas disease. Second report of the WHO Expert Committee. WHO Technical Report Series 905, WHO, Geneva, 120 pp.

WHO - World Health Organization 2010. First WHO report on neglected tropical diseases. Working to overcome the global impact of neglected tropical diseases. Available from: who.int/neglected_diseases/2010report/en/. 